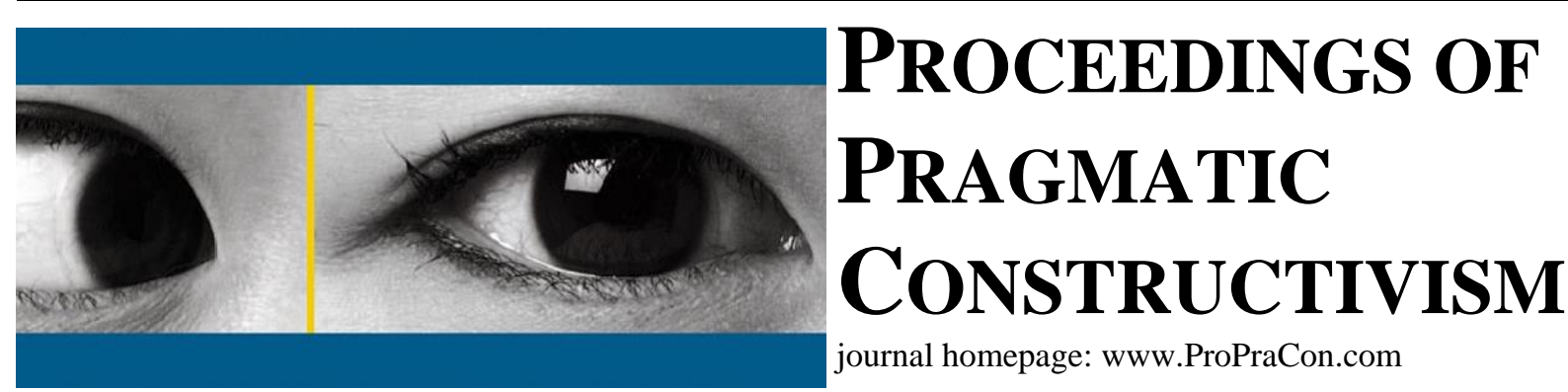

\title{
The family of constructivism and the contribution of a pragmatic dimension
}

\author{
Klarissa Lueg \\ Assistant Professor of Knowledge Communication \\ Aarhus University; School of Business and Social Sciences; Department of Business Communication \\ Jens Christian Skous Vej 4; 8000 Aarhus C; Denmark; lueg@asb.dk
}

Keywords: Constructivism; agent-centred management perspective; pragmatic dimension.

\section{Purpose}

Taking an agent-centred management perspective, this paper reviews several relevant streams of research and theory development in social constructivism in order to investigate the possible link for a pragmatic dimension. Whilst social constructivism and related theories and concepts have been (mis)perceived as either fostering an arbitrary perspective on or assessment of human action or "scepticism, critique and deconstruction" (Søderberg et al. 2002), pragmatic constructivism seems to be the only contemporary theoretical toolset that recognizes both structural constructions and the agents' capability of action from a management perspective.

\section{Methodology}

Conducting a comparative literature review of the development of social constructivism - from the construction of objectivity, knowledge, roles and dominance- and emerged specialized research fields and findings - such as gender, culture, tradition or national belonging - I demonstrate the consequences of these different streams for possibilities to act change and communicate on an agent's level. The comparison comprises theories such as relational realism, constructivist structuralism, realist constructivism, interactionist constructivism, and methodological constructivism. The pragmatic constructivism theory is examined as a basis for critical policy-development as well as a micro- and meso-level answer to constructivist research in fields that concern management and organizations.

\section{Expected findings}

First findings from the comparative literature review point to, that indeed the family of constructivism did not provide concepts that can enable management to realize and recognize "the productive and creative potential of its people" (Jakobsen et al. 2011: 2). Since pragmatic constructivism suggests that reality can be integrated by accounting for communication, possibilities, values and facts (ibid.: 20), it seems to originate a new paradigm, that is, no longer diagnosing that reality may be constructed, but asking how agents can be enabled to construct it.

\section{Possible directions of the discussion}

Discussions might touch upon the question how to cope with the legitimacy of the term "facts" or "factual knowledge" within a pragmatic constructivist framework. 


\section{Expected limitations and future research}

The research is in process. Thus, the list of reviewed publications and research streams is by far not exhaustive and might show a selection bias towards social science literature despite a strong constructivist tradition in science. Future research might find it useful to apply an ethical perspective to implications of social and pragmatic constructivism. A case study might further demonstrate the empowerment character of pragmatic constructivism.

\section{Originality}

Given the quality of pragmatic constructivism to function as an applicable framework for organizational analysis, development and change, the literature review implies that pragmatic constructivism is can be both aligned with other constructivist theories and used to create value for management and agents in organizations. 


\section{References}

Bandura, A. 2001. Social Cognitive Theory: An Agentic Perspective. Annual Review of Psychology, 52(1): 1-26.

Barkin, J. S. 2010. Realist Constructivism: Rethinking International Relations Theory. Cambridge: Cambridge University Press.

Berger, P. L., \& Luckmann, T. 1966. The social construction of reality: A treatise in the sociology of knowledge. New York: Double and Company.

Bourdieu, P. 1989. Social Space and Symbolic Power. Sociological Theory, 7(1): 14-25.

Henriksen, L. B., Nørreklit, L., Mølbjerg Jørgensen, K., Böhme Christensen, J., \& O’Donnell, D. 2004. Dimensions of Change. Conceptualising Reality in Organisational Research. Copenhagen: DJØF.

Hickman, L. A., Neubert, S., \& Reich, K. (Eds.). 2009. John Dewey Between Pragmatism and Constructivism: Fordham University Press.

Jakobsen, M., Johanson, I.-L., \& Nørreklit, H. (Eds.). 2011. An Actor's Approach to Management: Conceptual Framework and Company Practices. Copenhagen: DJØF

Kamlah, W., \& Lorenzen., P. 1984. Logical propaedeutic: Pre-school of reasonable discourse. Lanham, MD: University Press of America.

Rust, J. 2006. John Searle and the construction of social reality. London: Continuum.

Searle, J. R. 1995. The construction of social reality: simonandschuster.com.

Steffe, L., \& Gale, J. (Eds.). 1995. Constructivism in education. New Jersey: Lawrence Erlbaum Associates.

Søderberg, A.-M., \& Holden, N. 2002. Rethinking Cross Cultural Management in a Globalizing Business World. International Journal of Cross Cultural Management, 2(1): 103-121.

Tilly, C. 2002. Stories, identities, and political change. Oxford: Rowman \& Littlefield.

Von Glasersfeld, E. 1995. Radical Constructivism: A Way of Knowing and Learning. Studies in Mathematics. Bristol, PA: Taylor \& Francis. 